\title{
EFFECT OF PH ADJUSTMENT OF LIGNOCAINE AND LIGNOCAINE-BUPIVACAINE SOLUTION ON ONSET AND GRADE OF MOTOR BLOCKADE ACHIEVED AFTER EPIDURAL ANAESTHESIA
}

\author{
Neetu Chaudhary1, Nidhi Prabha Sehgal'2, Sumeet Chugh ${ }^{3}$
}

${ }_{1}^{1}$ Specialist, Department of Anaesthesia and Intensive Care, Dr. Baba Saheb Ambedkar Medical College and Hospital, New Delhi, India. ${ }_{2}^{2}$ Senior Specialist and HOD, Department of Anaesthesia and Intensive Care, Dr. Baba Saheb Ambedkar Medical College and Hospital, New Delhi, India.

3Specialist, Department of Anaesthesia and Intensive Care, Dr. Baba Saheb Ambedkar Medical College and Hospital, New Delhi, India. ABSTRACT

\section{BACKGROUND}

Epidural block has the advantage of a more gradual and predictable onset; however, the quality and extent of blockade varies widely with different drugs and techniques. To overcome the slow onset and intensity of epidural anaesthesia, various adjuvants have been added time and again. We wanted to determine the effects of pH adjustment of Lignocaine and Lignocaine-Bupivacaine solution on the onset and grade of motor blockade achieved after epidural anaesthesia in patients of either sex, undergoing routine and emergency orthopaedic, gynaecological, urological and lower abdominal surgeries.

\section{METHODS}

This was a randomized controlled trial study. 80 ASA grade I and II patients who had to undergo elective or emergency orthopaedic, gynaecological, urological and lower abdominal surgeries, were selected for the study. These were divided into 4 groups of 20 patients each on the basis of local anaesthetic used. Group I to receive $2 \%$ Lignocaine epidurally, Group II to receive Lignocaine + Sodium bicarbonate, Group III to receive Lignocaine + Bupivacaine and Group IV to receive Lignocaine+ Bupivacaine + Sodium bicarbonate.

\section{RESULTS}

The mean onset time for sensory block was fastest in Group II i.e. $4.05 \mathrm{~min}$ +/- 1.02. of all groups. It was slowest in group III i.e. 13.4 min. The grade of motor blockade achieved at $30 \mathrm{~min}$ was maximum in group II. The difference in intensity between groups I and II, and III and IV was statistically significant.

\section{CONCLUSIONS}

Alteration of $\mathrm{pH}$ of local anaesthetic solution for epidural block as well as mixing lignocaine and bupivacaine produces rapid onset with a more intense block achieved with improved quality and less incidence of missed segments. Patient satisfaction was also better in the alkalinized groups.

HOW TO CITE THIS ARTICLE: Chaudhary N, Sehgal NP, Chugh S. Effect of pH adjustment of lignocaine and lignocaine-bupivacaine solution on onset and grade of motor blockade achieved after epidural anaesthesia. J. Evolution Med. Dent. Sci. 2019;8(13):10561058, DOI: $10.14260 /$ jemds/2019/233

\section{BACKGROUND}

Epidural block has the advantage of a more gradual and predictable onset; however, the quality and extent of blockade varies widely with different drugs and techniques. To overcome the slow onset and intensity of epidural anaesthesia various adjuvants have been added time and again. $(1,2,3)$ Adding carbonated salts leads to $30 \%$ increase in effectiveness, in terms of both shorter latency and more intense quality of sensory and motor blockade. $(4,5)$ Raising the $\mathrm{pH}$ of local anaesthetic has been shown to shorten the onset time and time to peak effect and to increase the quality of block. $(6,3)$ These observations have been confirmed by comparing the alkalinized lignocaine (2\%) and alkalinised lignocaine $(2 \%)$ - bupivacaine $(5 \%)$ combination in terms of onset of action and quality of analgesia.(7)

'Financial or Other Competing Interest': None.

Submission 10-12-2018, Peer Review 16-03-2019,

Acceptance 23-03-2019, Published 01-04-2019.

Corresponding Author:

Dr. Nidhi Prabha Sehgal,

G-117, New Saraswati CGHS,

Plot No. 26/1, Sector 9,

Rohini-110085, New Delhi, India.

E-mail:doc_nidhi@rediffmail.com

DOI: $10.14260 /$ jemds $/ 2019 / 233$
This study includes comparison between lignocaine (2\%) and lignocaine $(2 \%)$ - bupivacaine $(5 \%)$ combination with their respective alkalinized forms to see -

1. Speed of onset and maximum height of sensory block.

2. Intensity of motor block.

3. Quality of analgesia.

4. Complications, if any.

\section{METHODS}

This randomized controlled trial study was conducted in the Department of Anaesthesiology, BSA Hospital and Medical College, Delhi. All patients classified by the ASA as physical status I and II were included in the study. These patients were to undergo elective or emergency orthopaedic, gynaecological, and urological and lower abdominal surgeries. Adult patients of either sex were included and allotted randomly to various groups by computer generated numbers. All 80 were divided into 4 groups of 20 patients each on the basis of local anaesthetic used. Unwilling patients, patients with h/o headache, backache, patients with coagulopathies and cardiac diseases, patients with hyper tension, neurological disorders, spinal deformity, skin infection of the back and those in shock were excluded from the study.

The four groups were as follows- 
1. Group I received $20 \mathrm{ml}$ of $2 \%$ lignocaine epidurally,

2. Group II received $15 \mathrm{ml}$ of $2 \%$ lignocaine $+5 \mathrm{ml}$ of sodium bicarbonate,

3. Group III received $10 \mathrm{ml}$ of $2 \%$ lignocaine $+10 \mathrm{ml}$ of $5 \%$ bupivacaine,

4. Group IV received $7.5 \mathrm{ml}$ of $2 \%$ lignocaine $+7.5 \mathrm{ml}$ of $5 \%$ bupivacaine $+5 \mathrm{ml}$ of $7.5 \%$ sodium bicarbonate.

\section{Sample Size}

In the absence of previous study, Cohen's effect size is used to calculate sample size. Assuming large scale effect size of 0.9 for time of onset of sensory block and intensity of motor block, the minimum required sample size with $80 \%$ power of study and two-sided alpha of $5 \%$ was 20 patients per group. So, sample size taken is 80 (20 per group).

\section{Formula used}

$\mathrm{n}>=\left(2^{*}\left(\mathrm{z}_{\mathrm{a}}+\mathrm{Zb}_{\mathrm{b}}\right)^{2} /(\mathrm{ES})^{2}\right.$

Where $\mathrm{z}_{\mathrm{a}}$ is value of $\mathrm{z}$ at two-sided alpha error of $5 \%$ and $\mathrm{zb}$ is value of $\mathrm{z}$ at power of $80 \%$ and $\mathrm{ES}$ is effect size. All patients had a Pre-anaesthetic check-up prior to surgery. Consent for epidural anaesthesia was taken, the back was examined for any deformity or infection and all routine investigations were done and patient's height was also measured. After preloading with $500 \mathrm{ml}$ Ringer lactate, epidural anaesthesia was administered at L2-3 or L3-4 interspace. Time of onset of anaesthesia which is the time required to produce loss of sensation bilaterally at L1 dermatome was recorded. Quality of analgesia was graded on a scale of I to III where I was complete analgesia, II required supplemental sedation and III required general anaesthesia cover. Intensity of motor blockade was assessed using modified Bromage scale.(5) Quality of anaesthesia was assessed keeping in mind the patient's as well as surgeon's satisfaction which was described as either good, fair or poor. Any complications intra or post operatively were mention on method of randomization.

\section{Statistical Analysis}

The data was analysed using SPSS-22 trial version. Socio demographic profile frequencies were calculated. Mann Whitney U and Kruskal-Wallis tests were used to compare data (Unequal sample size and non-normal distribution) between groups and Spearman's rank correlation coefficient test was used to find the nature of association between DUI and Disability scores. A P value of less than 0.05 is considered as statistically significant.

\section{RESULTS}

After taking informed consent of the patient, epidural anaesthesia was instituted, and various parameters of the block were observed in the intra and post-operative periods.

\begin{tabular}{|c|c|c|c|c|c|}
\hline Characteristics & Group-I & Group-II & Group-III & Group-IV & p \\
\hline Weight & $55.1+/-6.99$ & $55.45+/-7.46$ & $54.95+/-5.07$ & $53.15+/-7.50$ & $<0.05$ \\
\hline Age (Yrs.) & $32.7+/-7.73$ & $36.85+/-10.02$ & $33.2+/-13.30$ & $37.7+/-15.72$ & $<0.05$ \\
\hline Height (cms.) & $162.3+/-5.38$ & $161.2+/-4.99$ & $162.7+/-3.30$ & $163.10+/-5.09$ & $<0.05$ \\
\hline Type of Surgery & 11 & 11 & 11 & 9 & \\
a) Lower Abdominal and Perineal & 2 & 4 & 4 & 6 & 5 \\
b) Hip to Knee & 7 & 5 & 5 & \\
c) Below Knee & & & & \\
\hline \multicolumn{7}{|c|}{ Table 1. Demographic and Clinical Characteristics of Study Patients (N=80) } \\
\hline
\end{tabular}

Mean weight ranged from 53.15 to 55.45 . The weight (mean+/- SD) difference between the groups were not statistically significant.

The age (mean +/-SD) and height (mean +/- SD) difference between the groups were statistically not significant.

\begin{tabular}{|c|c|c|c|c|c|}
\hline Group & I & II & III & IV & p \\
\hline Onset & $\begin{array}{c}7.6 \mathrm{~min} \\
+/-\end{array}$ & $\begin{array}{l}4.05 \\
\text { Tin }+/-\end{array}$ & $\begin{array}{l}13.4 \mathrm{~min} \\
+/-1.71\end{array}$ & $\begin{array}{c}6.65 \mathrm{~min} \\
+/-1.49\end{array}$ & $<0.05$ \\
\hline \multicolumn{6}{c|}{ Table 2. Time of Onset of Sensory Blockade } \\
\hline \multicolumn{6}{|c|}{ p Value $<0.05$} \\
\hline
\end{tabular}

The mean onset time was fastest in group II i.e. $4.05 \mathrm{~min}$. It was slowest in group III i.e. $13.4 \mathrm{~min}$. The comparison of time of onset between different groups was highly significant where $\mathrm{p}$ value $<0.05$. The comparison of maximum segmental level of analgesia was not statistically significant.

\begin{tabular}{|c|c|c|c|c|}
\hline Group & $\mathbf{0}$ & $\mathbf{1}$ & $\mathbf{2}$ & $\mathbf{3}$ \\
\hline I & 0 & 5 & 12 & 3 \\
\hline II & 0 & 0 & 7 & 13 \\
\hline III & 8 & 8 & 4 & 0 \\
\hline IV & 4 & 4 & 9 & 3 \\
\hline Table 3. Different Grades (Bromage Scale) of Motor \\
Blockade Achieved in The 4 Groups at 30 min. \\
\hline \multicolumn{6}{|c|}{ p Value < 0.05 }
\end{tabular}

In table 3 are shown the different grades of paralysis achieved according to Bromage scale at $30 \mathrm{~min}$. Full paralysis was maximum in group II (Grade 3). The difference in intensity of motor blockade between the groups was highly statistically significant where $\mathrm{p}$ value $<0.05$

In group I and II 10\% Required Mephentermine between $0-10 \mathrm{~min}$ in the post epidural period and 1 patient between 11 $20 \mathrm{~min}$. In group II, 2 patients required mephentermine between 0-10 min. In group III and IV mephentermine was not required. Atropine was administered to 1 patient in group II none of the other patients required atropine.

\begin{tabular}{|c|c|}
\hline Group & No. of Patients \\
\hline I & 4 \\
\hline II & 1 \\
\hline III & 5 \\
\hline IV & 1 \\
\hline \multicolumn{2}{|c|}{ Table 4. Number of Patients Requiring Supplementation } \\
\hline
\end{tabular}


The largest no of patients requiring supplementation was in the non-alkalinized group one patient in group III and IV required supplementation.

Overall patient satisfaction was greater in group III and IV.

\section{DISCUSSION}

The commercially available local anaesthetic solutions are all acidic (pH 3.0 to 6.5). The $\mathrm{pH}$ of lignocaine and lignocainebupivacaine combination used in our study was 6.96 and 6.98 respectively.

Local anaesthetic activity is dependent on nerve membrane penetration by the non-ionized local anaesthetic, the quality of which depends on the $\mathrm{pH}$ of the tissue fluid.(8) This unitary hypothesis of Hille and studies by Ritchie provide the basis for $\mathrm{pH}$ adjustment of local anaesthesia. $(9,10,11)$

In our study we increased the $\mathrm{pH}$ of local anaesthetic by alkalinizing them with $5 \mathrm{ml}$ of $7.5 \%$ sodium bicarbonate prior to injection. On alkalinization, $\mathrm{pH}$ of alkalinized lignocaine became 7.83 and that of alkalinized lignocaine-bupivacaine combination increased to 7.98.(7) found the $\mathrm{pH}$ of alkalinized lignocaine and alkalinized lignocaine-bupivacaine combination to be 7.54 and 7.62 respectively which is the same as our study. Gomber used $2 \mathrm{ml}$ sodium bicarbonate in $18 \mathrm{ml}$ of $2 \%$ lignocaine.(12)They however used xylocaine with adrenaline. Curatolo used $2 \mathrm{ml}$ soda bicarbonate with $20 \mathrm{ml} 2 \%$ xylocaine they however used $8.4 \%$ sodabicarbonate. (13) Rapid onset of sensory block with $\mathrm{pH}$ adjustment of local anaesthetics was due to improved penetration and more availability of the diffusible base.(1) A greater than $50 \%$ decrease in onset time for epidural anaesthesia took place when the $\mathrm{pH}$ was raised from 4.5 to 7.2 by addition of soda bicarbonate. However, adding $1 \mathrm{ml}$ of soda bicarbonate to 10 $\mathrm{ml}$ of lignocaine lead to slight delay in onset as compared to our study which is explained the low dose of soda bicarbonate used.

The onset time of bupivacaine was longer than lignocaine as the pKa of bupivacaine is 8.1 compared to 7.86 of lignocaine which is closer to the physiological $\mathrm{pH}$ of 7.4. Thus, the availability of unionized fraction of bupivacaine to be taken up by the nervous tissue was less than that of lignocaine.(14) In our study we used low dose of local anaesthetic in alkalinized group this may be the reason for the same segmental spread in all groups.

The mean intensity of motor blockade was more in alkalinized group in our study. $\mathrm{CO} 2$ based solutions showed a 60-65\% improvement in the intensity of block over the result with equivalent hydrochloride salt.(15) the degree of motor blockade was increased by $42 \%$ over controlled values with carbonated base which were found to have a $\mathrm{pH}$ of 7.3. The requirement of supplementation to epidural anaesthesia showed a gross difference between alkalinized and nonalkalinized forms. It was found that alkalinization of local anaesthetic solutions produces a more profound sensory block in the L5-S1 segments, improving the quality and symmetry of block that were produced, problems of missed segments and unilateral blocks were not seen. $(3,14,6)$ There was no significant difference between MAP and pulse rate of the groups, no major complications were observed in any of the groups.

\section{CONCLUSION}

Alteration of $\mathrm{pH}$ of local anaesthetics for epidural block produces rapid onset of block. The intensity of motor blockade too increased with alkalinization with an improved quality block and less chances of missed segments. As it produces no haemodynamic and neurological complications, this practice can be safely used in day to day anaesthesia.

\section{REFERENCES}

[1] Bromage PR. Epidural analgesia.1 ${ }^{\text {st }}$ edn. Philadelphia: W B Saunders 1978: p. 314.

[2] Difazio CA, Carron H, Grosslight KR, et al. Comparison of $\mathrm{pH}$-adjusted lignocaine solutions for epidural anaesthesia. Anaesth Analg 1986;65(7):760-4.

[3] Galindo A. PH adjusted local anaesthetic: clinical experience. Reg Anaesthn 1983;8:35-6.

[4] Bromage PR. Improved conduction blockade in surgery and obstetrics: carbonated local anaesthetics. Can Med Assoc J 1967; 97(23):1377-84.

[5] Bromage PR. A comparison of the hydrochloride and carbon dioxide salts of lignocaine and prilocaine in epidural anaesthesia. Acta Anaesthesiol Scand Suppl 1965;16:55-69.

[6] Doughlas MJ, Mcmorland GH, Jeffery WK, et al. The effects of $\mathrm{pH}$ adjustment on epidural anaesthesia for caesarean section. Anaesthesiology 1986;65:A380.

[7] Gaggero G, Meyer 0, Van Gessel E, et al. Alkalinization of lignocaine $2 \%$ does not influence the quality of epidural anaesthesia for elective caesarean section. Can J Anaesth 1995;42(12):1080-4.

[8] Ritchie JM, Ritchie B, Greengard P. The effect of nerve sheath on the action of local anaesthetics. J Pharmacol Exp Ther 1965;150(1):160-4.

[9] Ritchie JM, Ritchie B, Greengard P. The active structure of local anaesthetics. J Pharmacol Exp Ther 1965;150(1):152-9.

[10] Hille B. Local anaesthetics: hydrophilic and hydrophobic pathways for the drug-receptor reaction. J Gen Physiol 1977;69(4):497-515.

[11] Ritchie JM, Greengard P. On the active structure of local anaesthetics. J Pharmacol Exp Ther 1961;133(2):2415.

[12] Gomber S, Aggarwal S, Gomber KK, et al. Epidural anaesthesia with $\mathrm{pH}$ adjusted lignocaine with adrenaline. Commercial vs fresh preparation. J Anaesth Clin Pharmacol 1993;9(1):11-4.

[13] Curatolo M, Peterson-Felix S, Arendt-Nielsen L, et al. Adding sodium bicarbonate to lidocaine enhances depth of epidural blockade. Anesth Analg 1998;86(2):341-7.

[14] Atkinson RS, Rushman JB, Lee JA. Regional analgesia. In: A synopsis of anaesthesia. 10 th edn. Bristol: IOP Publishing 1987: p. 596.

[15] Catchlove RF. The influence of $\mathrm{CO}_{2}$ and $\mathrm{pH}$ on local anaesthetic action. J Pharmacol Exp Ther 1972;181(2):298-309. 